\title{
Waste Disposal Practices and its Environmental Implications
}

\author{
Fakorede C. O.*, Anguruwa G. T., Ajayi O. B. and Odega C. A. \\ Forest Products Development and Utilization Department, Forestry Research Institute of Nigeria, Ibadan, Oyo \\ State, Nigeria \\ Corresponding Author: *lovemonami@yahoo.com
}

https://doi.org/10.36263/nijest.2021.02.0284

\begin{abstract}
Waste generation is inevitable in every human society, although methods of disposal may differ from region to region especially developing and developed nations, yet waste disposal is generally necessary. This study therefore investigated waste disposal practices amongst residents of Oluyole local government area of Ibadan, Oyo State. It was observed that (44.4\%) and (32.4\%) of the residents dumped their household refuse with government and private waste collectors respectively, but majority utilized improper waste disposal methods such as dumping in rivers (10.3\%), roadsides(14.8\%), open dumpsites (20.4\%), gutter (9.3\%), and open-air burning(33.3\%). Larger proportion $(97.5 \%)$ of the respondents strongly agreed that indiscriminate waste dumping has inimical environmental implications such as flooding, disruption of aesthetic beauty, disease, river pollution amongst others. In order to bring the situation under control, the respondents prefer the full involvement of the government waste collection agency instead of private waste collectors. It is therefore recommended that government waste collector should be empowered to penetrate more traditional core areas for more effective waste collection.
\end{abstract}

Keywords: Waste, Improper, Open-air burning, Flood, Disease

\subsection{Introduction}

Human population is currently on the rise everywhere around the world especially Africa, and Nigeria in particular might possibly experience rapid population growth in some years to come (World Population Prospects, 2017). From time immemorial human beings have been known for leaving behind residues or wastes from their various activities, hence the larger the population the most likely the amount of waste generated (Organization for Economic Cooperation and Development, 2015). Waste is a major environmental challenge of all times and is a serious threat to environmental aesthetic beauty and health especially in regions where they are not properly managed (Fellman et al., 2005; Hettinger, 2007).

Huge tons of municipal wastes are generated globally on daily basis. While some regions might be managing their waste properly, several others especially the developing nations are perceived unable to manage their huge urban waste. It has been observed that much garbage are usually left uncollected in the streets, polluting the environment (Nyang'echi, 1992; Zia et al., 2008).

Municipal solid wastes are unwanted materials mainly consisting of household wastes and are therefore referred to as household garbage (Ramachandra et al., 2018). The rapid growth of the world's population, urbanization, the socioeconomic development, and the improvement of living standards has raised the municipal solid wastes' generation globally (Karak et al., 2012). Their quantity has increased over the years in the developing countries. Waste management faces many difficulties from the technical and the organizational sides. Facing this reality, open landfills (dumpsites), open- air burning, dumping on water bodies amongst many other indiscriminate disposal methods have become the only available way for their elimination (Pastor et al.,2012).

Indiscriminate dumping of refuse has been observed to be very detrimental to the environment (Ejaz et al., 2010; Eche et al., 2015; Cogut, 2016). In that, many flood episodes in Nigeria were observed to be caused by improper waste management, where in most cases the available drainages are often 
blocked by waste (Yongsi et al., 2008). In recent decades, open landfill is still worldwide and very common means of municipal solid wastes' removal especially in developing countries where it is perceived to be the simplest and most economical waste disposal practice (Breza-Boruta et al., 2016). These open landfills have led to serious sanitary risks in that insect vectors of a lot of diseases are harboured within (Yongsi et al., 2008). They also constitute nuisance and considerable environmental impacts by the production of both leachate (confirmed to be a conveyor of heavy metals, organic matter, and pathogenic bacteria which has been known to cause pollution of soils, surface water, and ground water), and biogas whose emissions can increase greenhouse effect and global warming, particularly the highly flammable methane and hydrogen which can lead to fire or explosion if not properly managed (Aronsson et al., 2010; Deng et al., 2017). Open burning of waste is a common practice in several places around the world. It has been observed to be prevalent in rural areas all over the world. Worldwide scientific research has decisively showed that burning of waste at landfills produces a wide range of toxic substances lethargic to the environment and its health (Cogut, 2016). Recent research demonstrates that backyard burning of waste can increase the risk of heart disease, intensify respiratory ailments such as asthma and emphysema and cause rashes, nausea, or headaches, damages in the nervous system, kidney or liver, in the reproductive and development system(Igoni et al.,2007, Babayemi and Dauda, 2009; Cogut, 2016). In order to enhance the formulation and or implementation of proper waste management policies towards reducing or possibly eradicating indiscriminate waste dumping, this study therefore, considers it reasonable to investigate household waste disposal practices amongst residents of Oluyole local government area of Oyo state. Towards creating awareness on the need to properly manage household waste, for cleaner and healthy environment.

\subsection{Methodology}

\subsection{Study area}

Oluyole local Government area of Oyo state (DMS Coordinates 70 13 '59. 99" N 30 52' 0.01"E) has its headquarters in Idi- Ayunre. The local Government Area consist of Wards and villages such as Ekefa, Seko, Ayegun, Idi-Iroko, Idi-Osan, Egbeda-Atuba, Muslim Ogbere, Odo-Onanla, Okanhinde, Latunde,Olomi/Olunde, Orisunbare, Onipe, Ojo-Ekun, Aba.Nla. This local Government is one of the oldest in Oyo state which was created in 1976. It has a landmass of $629 \mathrm{~km}^{2}$ and a population of 202,725 at the 2006 census (www.oyostate.gov.ng). It shares boundaries with four local government areas which are Ibadan southwest, south east, Ona Ara and Ido. The age group in the area is as follows $(0-4$ years $-78,135 ; 15-64$ years $-118,145 ; 65+$ years $-7,181)$. The total number of males according to 2006 census was 102,371 while 101,090 were recorded for the females (www.oyostate.gov.ng). It is a mixed settlement comprising low, medium and high-density residential areas. Dominant occupations in this area are trading, public services and farming 


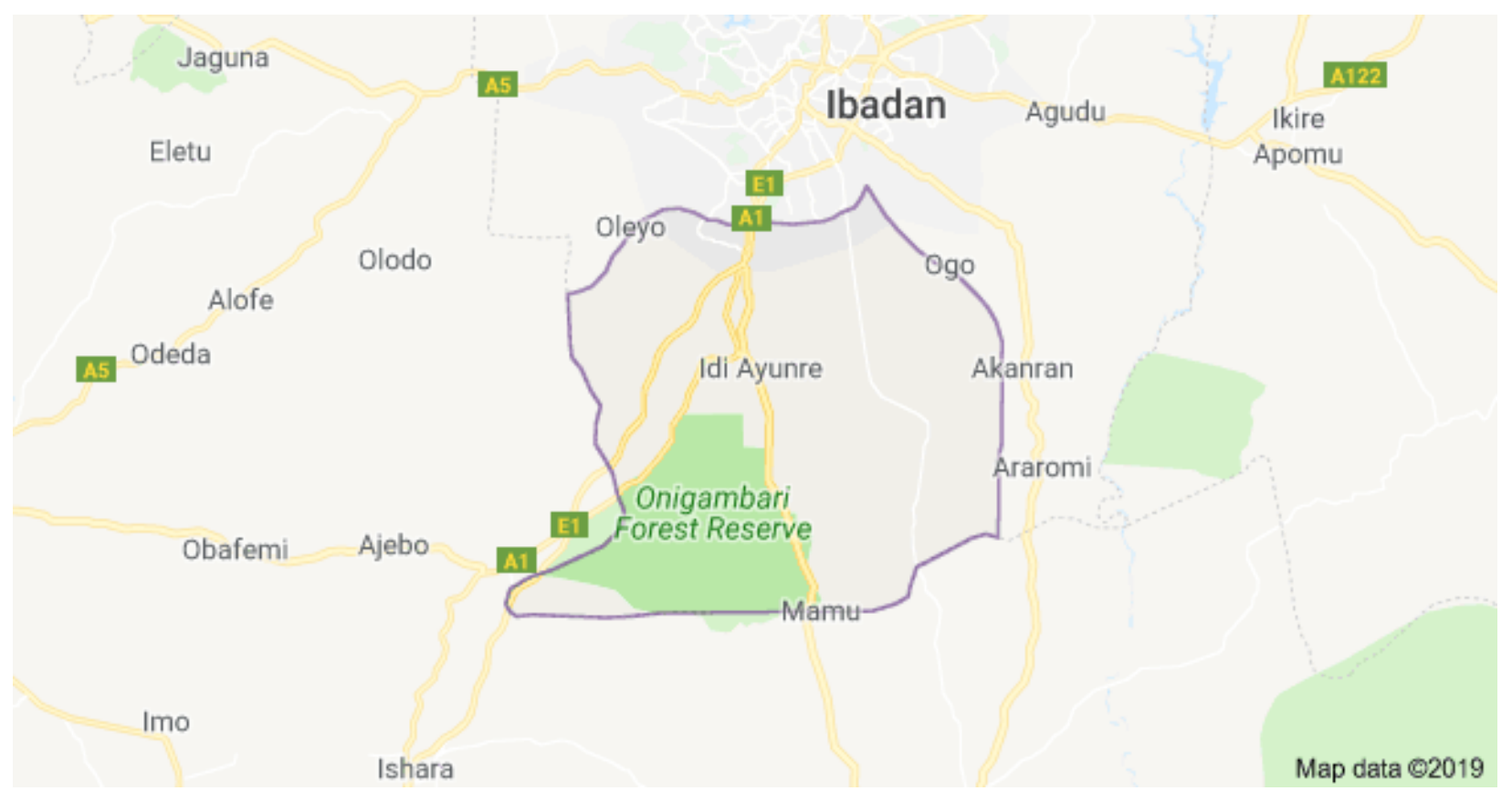

Figure 1: Map showing Oluyole Local Government Area. Source: Map data, 2019

\subsection{Design}

The study was descriptive by design and it utilized quantitative method for data collection. Using a well-structured, cross-sectional questionnaire, distributed by a trained extension officer to a hundred and fifteen (115) households randomly selected. The questionnaire has five different sections which provided information on household and demographic characteristics, Types of waste, Waste disposal methods, perceived consequences of improper waste disposal and proposed solutions. The questionnaire was designed based on the objectives of the study and review of available literature. The study area was purposively selected because it is an ideal combination of the low, medium and high-profile community/households where all classes of respondents could be found.

\subsection{Data analysis}

The data were analysed using SPSS, version 16 (IBM, Chicago, IL, USA). Descriptive statistics were used for the variables.

\subsection{Results and Discussion}

\subsection{Types of waste in the study area}

In Figure 2, the percentage of waste types generated in the study area were presented as follows; bottles/can/paper was $60.2 \%$, while food debris was $51.9 \%$, plastics was $38 \%$ and clothing materials had the least that is $25 \%$, all these were categorized as domestic waste. Although, this work does not look into other categories of waste, it could still be considered in tandem with the estimate made by (Adewumi et al., 2005) that domestic waste was the highest in quantity amongst waste categories generated in Ibadan metropolis. Gwedu (2003) observed that waste generation was directly related to population distribution within the city and that the inner core area generated highest volume of solid waste, this might be attributed to the absence of waste collectors either private or government in such areas, as considerable number amongst the respondents in the inner areas reported that waste collectors do not come to their areas. 
FOOD DEBRIS

BOTTLE/CAN/PAPER
PLASTICS

- CLOTHING MATERIALS

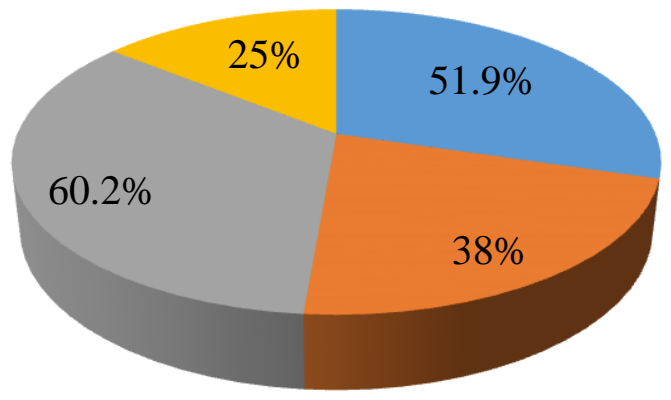

Figure 2: Types of waste in the study area

\subsection{Waste Disposal Practices in the study area}

Figure 3 shows the common waste disposal practices in the study area. The largest proportion (44.4\%) of the respondents disposed their waste with government waste collectors. $32.4 \%$ of the respondents chose waste management agencies owned by private individuals. $33.3 \%$ were involved in open burning of waste. $20.4 \%$ of the respondents dumped their waste on open dump sites. $14.8 \%$ leaves their waste along roadside. $10.3 \%$ dumps waste on Rivers or any water bodies while $9.3 \%$ dumps waste in gutter. Although certain proportion of the residents patronizes private and Government agencies, improper waste management was still very rampant as evident in the pictures (Plates 1 and 2). Although the largest proportion of the residents and respondents affirmed their awareness about the environmental menace of indiscriminate waste dumping yet, they were engaged in such inimical practices. This might be due to the necessity of waste disposal. Majority dump their waste in undesignated areas such as gutter, roadside, open dumpsites, this was also observed amongst poor Ibadan residents by (Ogungbuyi, 2013). The waste disposal practices identified in the study area is in consonance with the work of (Oguntayo and Obayelu, 2013) who in their project identified Government/dumpsite waste collection, landfill/burning, dumping into river/drainage and roadside as the most prominent waste disposal practices in Ibadan. Most of the residents complained of the untimely intervention of both private and Government waste collectors. This slow intervention pace might be attributed to the long distance and nature of most of the core areas. Omole et al. (2013) also affirmed that residents in the core areas often walked long distance before having access to waste container or collection points.

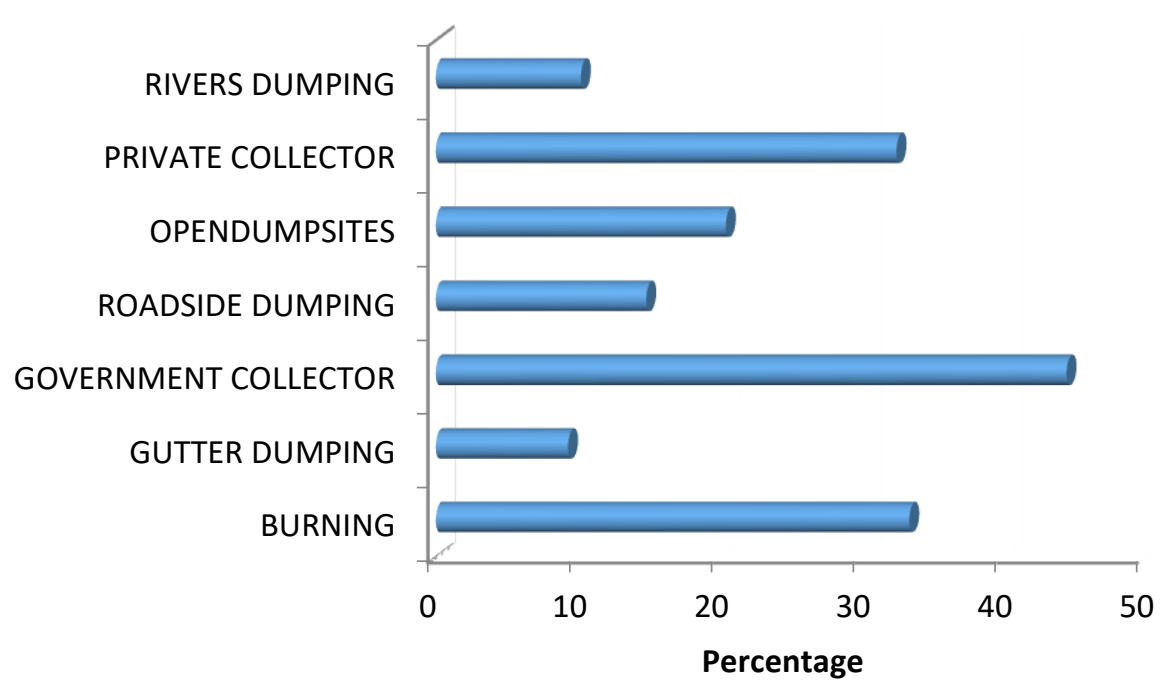

Figure 3: Waste disposal practices in the study area 


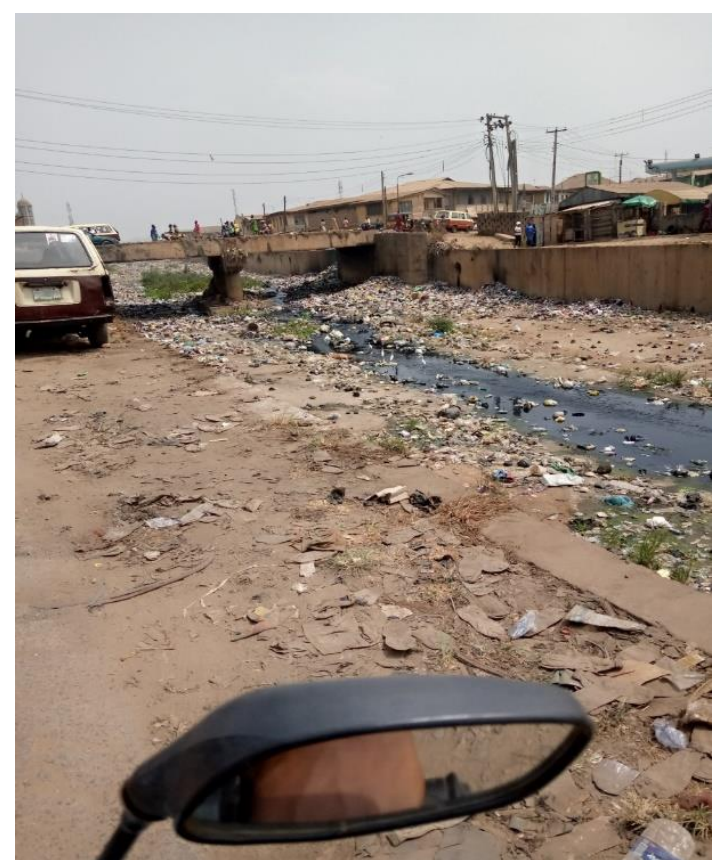

Plate 1: Waste disposal on river canal/drainage (Field Survey, 2021)

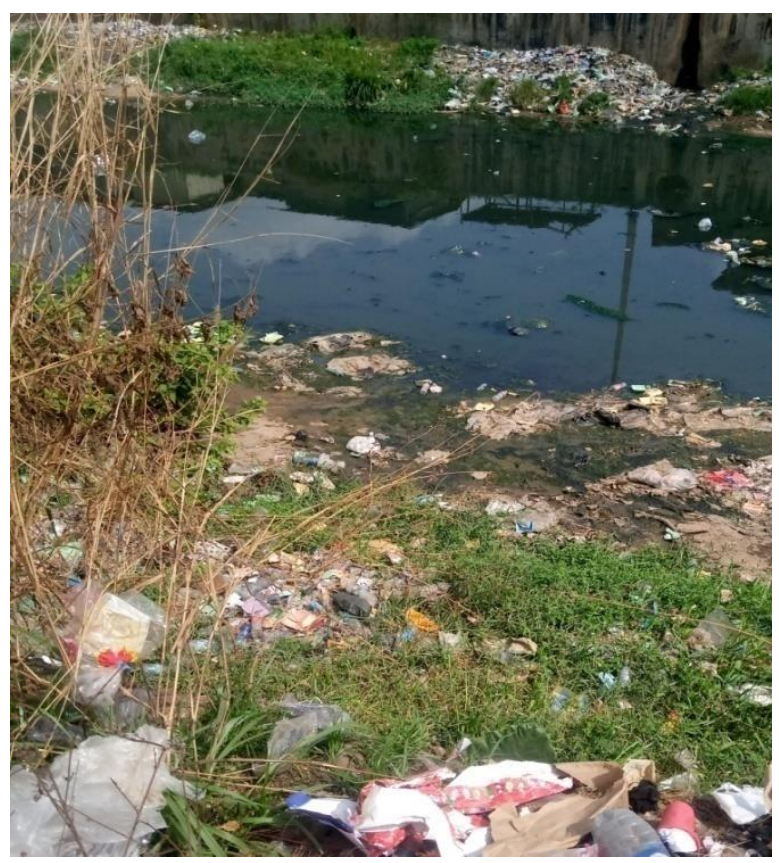

Plate 2: Pollution of water by waste (Field Survey, 2021)

\subsection{Awareness on the environmental menace of indiscriminate waste dumping}

Figure 4 reveals that a very significant number of the respondents are aware of the environmental implications of indiscriminate dumping of waste as $91.7 \%, 88 \%, 91.7 \%$ and $91.7 \%$ respectively agreed that dumping waste indiscriminately can cause flooding, water pollution, disease, and disrupt Environmental aesthetic beauty. 2\%,3.7\%, $0.9 \%$ and $1.9 \%$ disagreed that indiscriminate dumping can cause flooding, water pollution, disease, and disrupt Environmental aesthetic beauty respectively. While $6.5 \%, 7.4 \%, 5.6 \%$ and $0.5 \%$ are not aware that flooding, water pollution, disease, and disruption of Environmental aesthetic beauty can be caused respectively by indiscriminate dumping. Despite this awareness by a vast majority there is still a need to bring to the fore, the findings by (Szymanski et al., 2018) that discovered that improper waste management has caused bad odour, food contamination, breeding of mosquitoes, cockroaches and flies leading to disease epidemics such as malaria and cholera. Dumping of waste on water bodies can also be toxic to fishes and if such fishes are consumed can lead to food poisoning.

Ogungbuyi (2013) also discovered that improper waste management has led to human-induced menace such as flooding because of the blockage of water ways and river canals. Ogunbode et al. (2013) observed that larger percentage of the population have now resulted into open burning of waste, and this act has been observed to be very deleterious to the environment and its health. Dumping of household products, pesticides and other materials create a danger to public health and the environment and also the incomplete combustion of waste during open burning contributes to air pollution and climate change (National Environmental Engineering Research Institute, 2010). Lee et al., (1995) also reported that Small Particulate matter are usually released to the environment through waste burning and this has the ability of entering into lungs and thus cause respiratory problems, such as asthma and inflammation of the airways. 


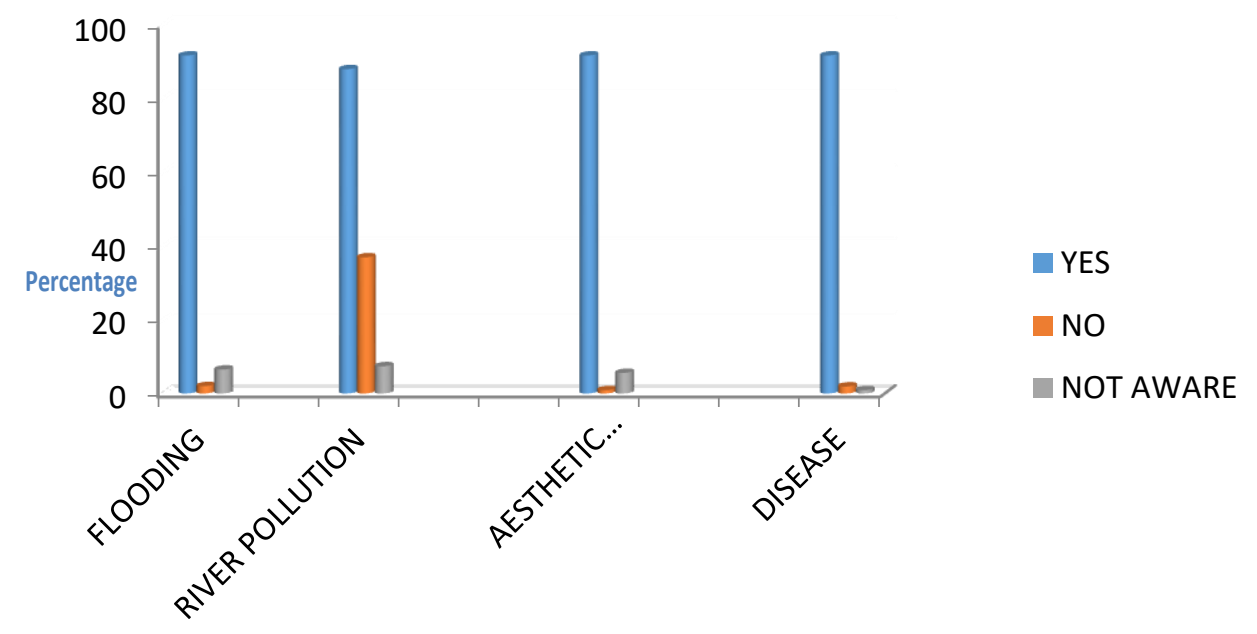

Figure 4: Awareness of respondents on the effect of indiscriminate waste dumping

Another poisonous element released into the environment during waste burning (especially through burning of wood, coal, etc.) is polycyclic aromatic hydrocarbons (PAHs). These hydrocarbons were reportedly able to cause cancers, genetic mutations and birth defects (Valavanidid et al., 2008).

\subsection{Proposed Solution to indiscriminate waste Dumping}

In Table 1, larger percentage (69.4\%) of the respondents strongly agreed that Government organizations should take charge of waste collection, $16.7 \%$ partially agreed while $8.3 \%$ disagreed with that notion, $25.0 \%$ disagreed that Private waste management companies should be allowed to take full charge of waste management $41.7 \%$ and $20.4 \%$ respectively strongly and partially agreed that the total involvement of private individuals will help reduce or eliminate indiscriminate dumping of waste. Higher preference for government waste collectors was recorded and according to many of the respondents, this was because their waste were collected free of charge especially when they carry their waste to collection points. Although, many of them attested to the effectiveness of private companies yet preference for them was low, this might be attributed to their charges. Oguntayo and Obayelu (2013) also realized this during their own research work that $10 \%$ of waste producers employed the service of private waste collectors with an average monthly pay of 2,000 Naira while $41 \%$ used Government waste services with average monthly charge of 500 Naira. Private waste collectors collect waste from clients who are willing to pay for their service.

Table 1: Perception of respondents on solution to indiscriminate dumping of waste

\begin{tabular}{|l|c|c|c|}
\hline Individual Ideas & Strongly Agree (\%) & Partially Agree (\%) & Disagree (\%) \\
\hline $\begin{array}{l}\text { Waste collection should be fully handled by } \\
\text { the Government }\end{array}$ & 69.4 & 16.7 & 8.3 \\
\hline $\begin{array}{l}\text { Waste collection should be handled by private } \\
\text { organisations }\end{array}$ & 41.7 & 20.4 & 25.0 \\
\hline
\end{tabular}

\subsection{Conclusions}

It was observed during the course of this study that most of the respondents in the study area manage their waste improperly. Vast majority are aware of the environmental implications of indiscriminate waste dumping. Moreover, larger percentage of the respondents prefers government refuse collectors to their private counterparts. Government waste collector should widen their scope to cover more areas especially the traditional core areas of Ibadan.

\section{References}

Adewumi, I. K., Ogedengbe, M. O., Adepetu J. A. and Fabiyi, Y. L. (2005). Planning organic fertilizer industries for municipal solid waste management. Journal of Applied Science Research, 1(3), pp. $285-291$. 
Aronsson, P., Dahlin, T. and Dimitriou, I. (2010). Treatment of landfill leachate by irrigation of willow coppice - plant response and treatment efficiency. Environmental Pollution, 158(3), pp. 795804.

Babayemi, J. O. and Dauda, K. T. (2009) Evaluation of solid waste generation categories and disposal options in developing countries. A case study of Nigeria. Journal of Applied Science Environment and Management, 13(3), pp. 83-88.

Breza-Boruta, B., Lemanowicz, J. and Bartkowiak, A. (2016). Variation in biological and physicochemical parameters of the soil affected by uncontrolled landfill sites. Environmental Earth Sciences, 75(3), pp. 201-213.

Cogut, A. (2016). Open Burning of Waste A Global Health Disaster.[online] R20 Regions of Climate Action. Available at :https://regions20.org/wp-content/uploads/2016/08/OPEN-BURNING-OFWASTE-A-GLOBALHEALTH-DISASTER_R20-Research paper_Final_29.05.2017. [Accessed 13 Feb. 2020].

Deng, L., Liu, Y. and Zheng, D. (2017). Application and development of biogas technology for the treatment of waste in China. Renewable and Sustainable Energy Reviews, 70, pp. 845-851.

Eche, O. F., Yakubu, A. A., Lekwot, V. E., Kwasaba, D. A. and Daniel, S. C. (2015). An assessment of Plateau Environmental Protection and sanitation agency (PEPSA) as a waste management institution in Jos city, Nigeria. International Journal of Scientific \& Technology Research, 4(2), pp. 163-170.

Ejaz, N., Akhtar, N., Nisar, H. and Naeem, U. A. (2010). Environmental impacts of improper solid waste management in developing countries. A case study of Rawalpindi city. WIT Transactions on Ecology and the Environment, 142, pp. 379-387. doi:10.2495/SW100351.

Environmental Protection. [online] Charleston, USA. Available at www.environmentalphilosophy.org/Hettinger.[ Accessed 01 June,2006]

Fellman, J. D., Gettis, A. and Gettis, J. (2005). Human Geography $8^{\text {th }}$ Edition, ISBN-13:9780073259314.McGraw-Hill Science/ Engineering/Math.

Gwedu, T. (2003) Population, Development, and Waste Management in Botswana: Conceptual and policy Implications for Climate Change. Environmental management, 31, pp. 0348-0354.

Hettinger, N. (2005). Objectivity in Environmental Aesthetics and protection of the Environment. Beauty to Duty: from Aesthetics to Environmentalism. Edited by Carlson, A. and Lintott, S. Columbia University Press, New York.

Igoni, A. H., Ayotamuno, M. J., Ogaji, S. O. T. and Probert, S. D. (2007). Municipal solid-waste in Port Harcourt, Nigeria. Applied Energy, 200784(6):664670. DOI: https://doi.org/10.1016/j.apenergy.2006.12.00216.

Karak, T., Bhagat, R. M and Bhattacharyya, P. (2012). Municipal solid waste generation, composition and management: the world scenario. Critical Reviews in Environmental Science and Technology, 42(15), pp. 1509-1630.

Lee, H., Wang, L. and Shin, J. F. (1995). Mutagenicity of particulates from the laboratory combustion of plastics. Mutat. Res., 346, pp. 135-144.

National Environmental Engineering Research Institute, NEERI. (2010). Air Quality Assessment, Emissions Inventory and Source Apportionment Studies: Mumbai. 
Nyang'echi, G. N. (1992). Management of solid and liquid waste of Human Activities, Nairobi, Kenya McGraw-Hill, New York.

Ogunbode, E. B., Fabunmi, F. O., Ibrahim, S. M., Jimoh, I. O. and Idowu, O. O. (2013). Management of Sawmill wastes in Nigeria: Case study of Minna, Niger State. Greener Journal of Science, Engineering and Technology Research, 3, pp. 34-41.10.15580/GJSETR.

Ogungbuyi, K. (2013). Ibadan urban flooding management project. Ibadan: Baseline report on solid wastes management components. Environmental harmony, pp. 1-92.

Oguntayo, A. and Obayelu, A. (2013). Economic and Environmental Effects of Solid Waste Management in Ibadan Metropolis of Oyo State, Nigeria. Journal of Environmental Conservation Research, 1(2), pp $21-28$.

Omole, F. K. and Alakinde, M. K. (2013). Managing the unwanted materials: The agony of solid waste management in Ibadan metropolis, Nigeria. International Journal of Education and Research, 1(4), pp. 1-12.

Organization for Economic Cooperation and Development (OECD) (2015). Municipal Waste, Generation and Treatment: Municipal Waste generated per capita. OECD. StatExtracts.

Post Offices- with map of LGA. NIPOST. Archived from the original on 2012-11-26. [Retrieved Oct.2009].

Pastor, J. and Hernández, A. J. (2012). Heavy metals, salts and organic residues in old solid urban waste landfills and surface waters in their discharge areas: determinants for restoring their impact. Journal of Environmental Management, 95, pp. S42-S49.

Ramachandra, T. V., Bharath, H. A., Kulkarni, G. and Han, S. S. (2018). Municipal solid waste: generation, composition and GHG emissions in Bangalore, India," Renewable and Sustainable Energy Reviews, 82, pp. 1122-1136.

Szymanski, K., Janowska, B., Izewska, A., Slidelko, R. and Siebieslska, I. (2018). Method of evaluating the impact of landfill leachate on groundwater quality. Environmental monitoring and assessment, 190(7), pp. 415.

Valavanidid, A., Iliopoulos, N., Gotsis, G. and Fiotakis, K. (2008). Persistent free radicals, heavy metals and PAHs generated in particulate soot emissions and residual ash from controlled combustion of common type of plastics. Journal of Hazardous Materials, 156, pp. 277-284.

World population prospects: The 2017 Revision: Key Findings and Advance Tables. United Nations Department of Econnmic and Social Affairs, population Division. p.2.

Yongsi, H. B., Herrmann T. M., Ntetu A. L., Sietchiping R. and Bryant, C. (2008). Environmental Sanitation Risks on Tropical Urban Settings: Case Study of household refuse and diarrhoea in Yaounde-Cameroon. Int J Human Soc Sc. 2, pp. 158-166. doi.org/10.5281/zenodo.1055405

Zia, H. and Devadas, V. (2008). Urban solid Waste management in Kanpur: opportunity and perspectives. Habitat Int. 32, pp. 58-73. doi:10.1016/j. habitatint.2007.08.001.

Cite this article as:

Fakorede C. O., Anguruwa G. T., Ajayi O. B.' and Odega C. A., 2021. Waste Disposal Practices and its Environmental Implications. Nigerian Journal of Environmental Sciences and Technology, 5(2), pp. 387-394. https://doi.org/10.36263/nijest.2021.02.0284 